\title{
QUANTITATIVE AND QUALITATIVE EVALUATION OF PUBLIC TRANSPORT SUPPLY IN RURAL REGIONS CASE STUDY OF JESENÍK REGION
}

\author{
IGOR IVAN \\ Institute of Geoinformatics \\ VŠB-Technical University of Ostrava \\ 17. listopadu 15, Ostrava-Poruba, 70833 Czech Republic \\ e-mail: igor.ivan@vsb.cz
}

TOMÁŠ BORUTA

Department of Human Geography and Regional Development Faculty of Sciences, University of Ostrava

Kranichova 8, 71000 Ostrava-Slezská Ostrava, Czech Republic e-mail: tomas.boruta@osu.cz

\begin{abstract}
Commuting to work, school or basic services is going to be an important living condition in case of the Czech countryside. Level of public transport (PT) service was rapidly decreasing in nineties of the 20th century, which was caused by coincident of a few factors. The main goal of this paper is to analyse of PT supply level in the area in the Jeseník rural region (NUTS4-Jeseník District). The Jeseník region is one of the less developed Czech regions from many aspects (Rumpel et al. 2009), it contains 24 municipalities with approximately 41000 people. Analysis of PT connections frequencies and connection times in the region has showed quite positive situation during the evaluation of PT local service.

Keywords: rural area, public transport, Jeseník region, walking distance to stop
\end{abstract}

\section{INTRODUCTION}

The public transport (PT) service is considered as one of the key quality live attribute in rural areas, mostly in case of rural inhabitants groups who are more likely to be excluded in transport accessibility to main services (Kvizda et al. 2007) in more and more polarized rural space (White 2001; Woods 2005; Nutley 1998). The rural PT services situation and accessibility of rural inhabitants is often analyzed pheno- 
menon, which is a research object of geographers since the sixties of the 20th century (Hůrský 1969, 1978; Lijewski 1967; Green and Meyert 1997; Taylor 2003). Among the most important aspects of their research projects belong service regions creations inside the state (Hůrský 1978) or inside some smaller hierarchical spatial unit, commuting flows studies inside some area (Lijewski 1967; Sandow 2008) or transport behaviour of rural people (Nutley 1998). The research object was relatively different before 1990 because of different political-economical conditions in the Western Europe and in socialist countries in the Middle and Eastern Europe. In the countries, like the former Czechoslovakia was, the main role of PT services securing provided by the state. Hůrský (1969) says that, compared to Poland or Hungary, the ratio of economically active commuters was very significant ${ }^{1}$. So with low ratio of individual car transport, rural areas could have been facing the cities competition only with sufficiently established bus routes (since the Fifties, the volume of bus transport was more significant than train transport in former Czechoslovakia).

Rapid increase of automobilization level during Nineties was a logical result of a new social reality under the conditions of the Czech Republic, where the car characterized the social status and independent mobility. On the other hand, the car holding became not only previously written phenomenon but also a need, connected to decreased PT supply for guarantee of basic travels. But the economical situation of many rural people did not allow them to saturate the desire for independent mobility (car holding) in the same volume but with different causes as in some West European countries.

Commuting to work, school or basic services is becoming an important living condition already at local level in case of Czech countryside. The competence to guarantee basic transport service is in hands of the Regional Authorities since 2003, when the reformation of public administration was established. This reformation can be considered to be the most important change is organization system and financing of PT under the conditions of the Czech Republic. Decentralization from national to regional level increased the ratio of Regional Authorities emancipation, but some regional disparities in PT services between some regions are as a consequence (Ivan et al. 2009). That is caused by heterogeneous approach in PT organization (economical, space, modal, integrated) at the NUTS3 level.

The main goal of this paper is to analyse of PT supply level in the area of the Jeseník rural region (NUTS4-Jeseník District) in context of selected used methods (public transport connections frequencies, time accessibility, walking distances to stops in door-to-door approach and questionnaire survey). This region is one of the most backward Czech regions from many aspects (Rumpel et al. 2009), it contains 24 municipalities with approximately 41000 people. Its thwart and disparate development tendencies can be objectively proved by spatial-geographical evaluation as well.

\footnotetext{
1 There were almost $43 \%$ of economically active commuters in the Czechoslovakia in 1961. In Poland, the ratio was $21 \%$ (in 1964) and $12.5 \%$ in Hungary (Hůrský 1969).
} 


\section{CHARACTERISTICS OF ANALYZED AREA}

Jeseník region is one of five NUTS4 regions in the Olomouc region (NUTS3). It lies in the northern part near the Polish border and it consists of four micro-regions (totally 24 municipalities with 41000 people) with total area of $71896 \mathrm{~km}^{2}$. This region has the lowest regional population density ${ }^{2}$ and, based on the structural characteristics, it can be joined to typical rural peripheral regions with many socioeconomically problems. It is mostly mountain (part of PLA ${ }^{3}$ ) or foothill region with eccentric location to the rest of the Czech Republic with significant barrier of Jeseníky Mountains. Based on Marada (2003) results, there exists relative conformity between peripheral areas space distribution and transport peripheral areas. These areas are influenced by the localization of the country or region core centres and they are located logically near administrative borders of NUTS3 regions or the country border (both of these aspects are significant in case of Jeseník region). On the other hand, absence of wide transport demand caused by uncompetitiveness of surrounding NUTS4 regions, is a comparative advantage of this region (Seidenglanz 2007)_because of Jeseník border character (work relationship to Poland are negligible—see Rumpel and Wilam 2006) and because of mountain barrier between Jeseník, Bruntál and Šumperk NUTS4 regions.

Jeseník region has typical uniform distribution of towns and villages in the area. This situation creates big demands on the PT organisation within the region. On the other hand, it is relatively young type of rural settlement, so called lane lineal villages, where particular houses do not create continuous area (it is typical scattered Silesian settlement) and they are composed of two rows of houses along the road or stream (Láznička 1956). These municipalities have significantly elongated urban area, what has negative influence on walking distances to PT stops.

Roads network density and rate of automobilism ${ }^{4}$ has the lowest level with comparison to all other NUTS4 region in the Czech Republic. Lower rate of automobilism increases indirectly PT demands by particular groups of people (Sandow 2008; Dijst 1999). The trunk road is the road I/44 from Šumperk through this region to Poland and from the west-east connection point of view is the main trunk road $\mathrm{I} / 60$ from Jeseník to Bílý Potok (Figure 1). The trunk railroad is railway HanušoviceJeseník-Mikulovice, which passes the Jeseníky Mountain barrier over the saddle Ramzovské sedlo. On this national railway ${ }^{5}$ there are connected local railways Jeseník-Javorník (with turning to Velká Kraš_Vidnava) and Mikulovice-Zlaté Hory (Figure 1).

\footnotetext{
2 Jeseník region with 58 people per $\mathrm{km}^{2}$, Czech Republic 131 people per $\mathrm{km}^{2}$, Olomouc region with 122 people per $\mathrm{km}^{2}$.

3 Protected Landscape Area (PLA).

${ }^{4}$ In the Czech Republic, there is strong west-east gradient of this rate, if compare administrative NUTS4 regions. Rate of automobilism is abnormally influenced in cities and villages in comparison to the West Europe (rate of automobilism is mostly still bigger in rural areas here).

5 Based on law number 266/1994 Coll. about railways categorization.
} 


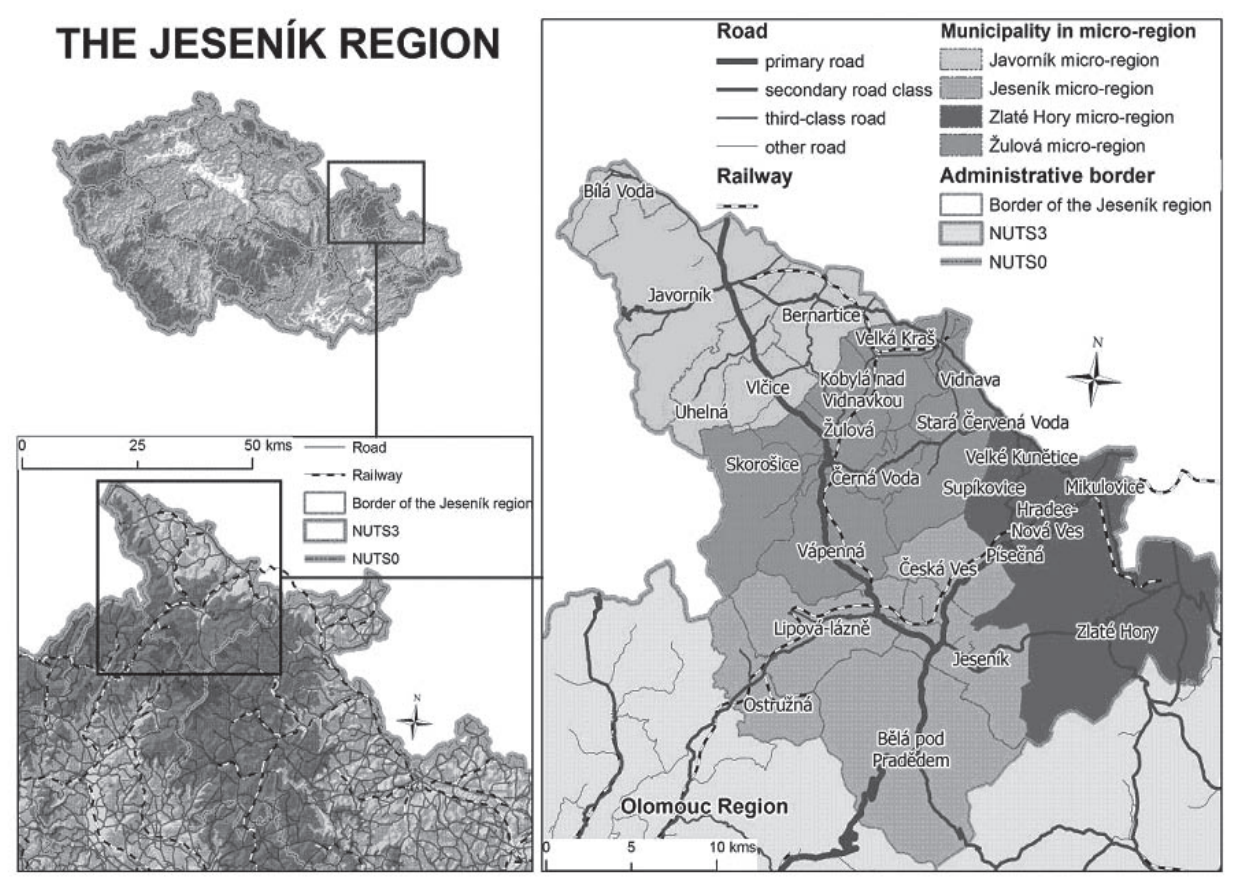

Figure 1. The Jeseník region

Source: own creation.

The analyzed region is today a part of the integrated transport system of the Olomouc region (ITSO, since 2003). In case of the Czech Republic, there is administrative principal of activity spatial limitation of ITSO. That means, ITSO are created under the direction of Regional Authorities (NUTS3), these take the role of ITSO coordinator very often, as well as in the Olomouc region. Creation and so-called optimalization of ITSO is regionally diverse process, which is connected to specific spatial structure of particular regions (White 2001). The Regional Authorities support financially the regional transport according to valid law in the mode of so-called "basic transport services". Mode of so-called "additional transport services" (mostly services during weekend) is then financed by municipalities.

In the Jeseník region there are two PT providers-bus (Veolia Transport Morava, Inc.) and train (Czech railways, Inc.). The modal split between individual car transport and PT was approximately 45 to $55 \%$ in the end of 20 th century 6 . According to general trends of decreasing rate of PT usage in middle European countries (Pucher 2002) today's ideal modal split should be 50 to $50 \%$ or worse in terms of PT-in context of the situation in west European countries where still significant ratio of people is using individual car transport. Bus transport has the key role of local transport service in the region; railway is used mostly to travel to longer distances where targets

\footnotetext{
${ }^{6}$ In 1998, the transportation survey was made within the analysed region and the share of modal split was constructed. Source: Studie optimalizace veřejné osobní dopravy v okrese Jeseník. UDIMO Ostrava, 1998
} 
are outside the target region. Different role of bus and rail transport is also influenced by the historical development of the railway network, which is mostly not applicable for today's door-to-door approach for commuting for short and medium distances.

\section{PT CONNECTIONS FREQUENCIES}

Number of PT connections which exist between municipalities inside the region and the city Jeseník in particular hours of interest were considered as one of main approaches how to analyse PT services of Jeseník region. These time intervals characterized three work shifts, because these are used for commuting to job and school most often. And these two types of spatial movements have the biggest importance and the intensity is biggest as well (Hampl 2005). Morning shift is represented by 6,7 and 8 o'clock, afternoon shift by 14 o'clock and night shift by 22 o'clock. The NEWDOK software was utilised for searching in PT time schedules (CHAPS, Ltd). The NEWDOK is being developed by the Institute of Geoinformatics, Technical University of Ostrava since 2001 (Fojtík 2009). This methodology was used by other regional researches and that is why it can be comparable (Horák et al. 2008). As the sufficient PT connection was considered everyone which fulfilled all conditions. The maximal duration of each PT connection has to be faster than 90 minutes and the arrival cannot be sooner than 60 minutes before shift start and the number of changes during the journey was limited to 5 .

These analyses of PT connection numbers and time accessibility were done in the time cut between the October 2003 and the October 2008. The year 2003 was chosen as the first referential year. The real changes of the reformation of public administration appeared firstly in this year (new NUTS3 regions and their responsibility for regional PT functioning).

Results of the 2008 analysis (Figure 2, first map field) prove very good PT accessibility of municipalities that are along the railway number 292 HanušoviceMikulovice, respectively along the road number 369, 60 and 44. PT connections supply (train and bus) is according to the results of questionnaires considered the best in the NUTS4 region, (see Boruta and Ivan 2008; Rumpel et al. 2009)—mostly in Česká Ves, Písečná and Lipová-lázně 7 that means in municipalities around the city Jeseník. PT operates for commuting in intervals similar to urban PT during peak hours in this area. The next research should focus on the real walking distances to used PT stops because of the municipalities' wide area. Žulová has confirmed its role as the local transport node; it guarantees connections to and from Žulová and Javorník microregion (from and to Jeseník).

If we compare total number of PT connections between 2003 and 2008 (second map field), it is obvious that the total number of PT connections is cumulatively about 51 connections higher in 2008. On the other hand in comparison to 2003 there

\footnotetext{
${ }^{7}$ Satisfaction with PT service between inhabitants in municipality Lipová-lázně is discussed in Chapter 6
} 

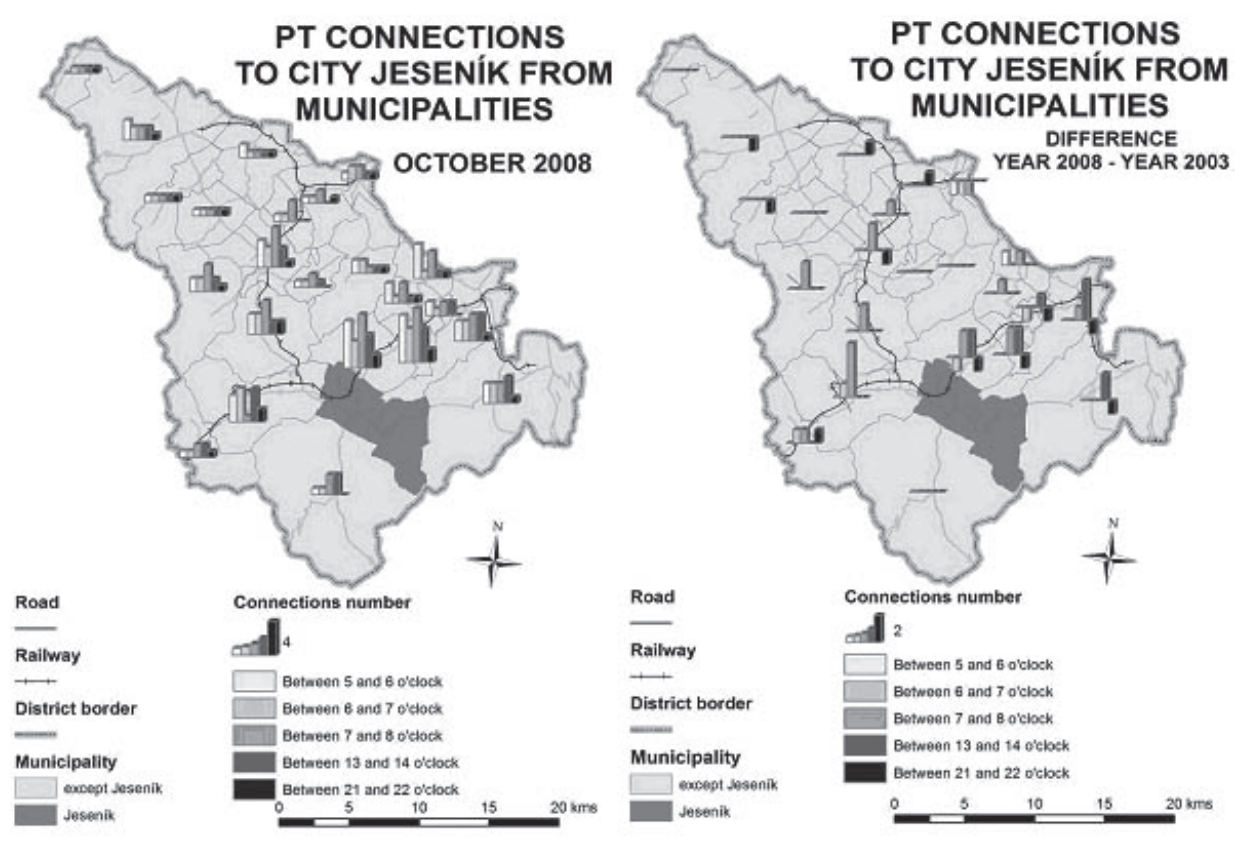

Figure 2. Number of PT connections to the city Jeseník Source: own creation.

is obvious a small decrease in PT connections for morning commuting to Jeseník (between 6 and 7 o'clock; Vidnava, Česká Ves, Hradec-Nová Ves). The small increase of morning PT connections to the regional centre is in case of 11 municipalities (mostly for arrival at 8 o'clock). On the other hand there is proved the so-called rationalization of night PT connections that relates to the municipalities with no connection from the city Jeseník after 21 o'clock during the work day (Bernartice, Bílá Voda, Černá Voda, Ostružná, Kobylá nad Vidnávkou and Velká Kraš). These municipalities have mostly railways (except Bílá Voda and Černá Voda).

\section{TIME ACCESSIBILITY OF JESENÍK}

The first map field (Figure 3) describes the situation in commuting time from particular municipalities to Jeseník for the morning shift (start at 8 o'clock) based on the same conditions as in the previous chapter. The worst situation in PT accessibility of Jeseník city is in the location of Javorník's hook (Javorník micro-region). It proves its geographical periphery even in the scale of Jeseník region (cross-border commute connections are minimal and not significant at this moment). This area is one of two most changed in the anamorphic map below, where the area is transformed based on commuting time to Jeseník. The network is much expanded in this area. Local people (residents) have to commute more than 45 minutes to Jeseník and this time 
interval can be considered as unattractive for commuters. The second area with massive expansion is in municipality Černá Voda and in surrounding municipalities like Vidnava, Velká Kraš and Kobylá nad Vidnávkou. The travel time to Jeseník from here is almost one hour! On the other hand quit good is the situation in municipalities near Jeseník. This is evident from the map, these municipalities area collapsed. The only exception is in Zlaté Hory, where only one fast train connection to Jeseník and its time influenced results in the map, otherwise the area would be more expanded. All other connections are longer and cancellation of this morning train connection would mean rapid decrease of PT service in relation to the regional centre.

Interesting situation is in case of transport node of municipality Žulová (Žulová micro-region). Due to manipulation durations at the main stop in the municipality (changes of routes, correction of delays, and others), this municipality area rose a little bit as well from the connection time aspect. But its real PT service is sufficient from the aspect of commuting time and connections frequency (junction of a few routes from other municipalities).

In the second map field there are showed changes in commuting time between the October 2003 and the October 2008. There is an evident progress in case of municipalities in the Javorník's hook (Bílá Voda and Javorník). From here, the travel time is now faster about 5-8 minutes. But biggest improve is in Ostružná with 11 minutes. Some rapid decline caused only one municipality in the region-Skorošice with 7 minutes longer time. Situation in other municipalities is without any significant change, so in result the development during five years could be found as positive.

\section{COMMUTING TIME FROM MUNICIPALITIES TO JESENIK IN 2008 AND CHANGE BETWEEN 2003 AND 2008}
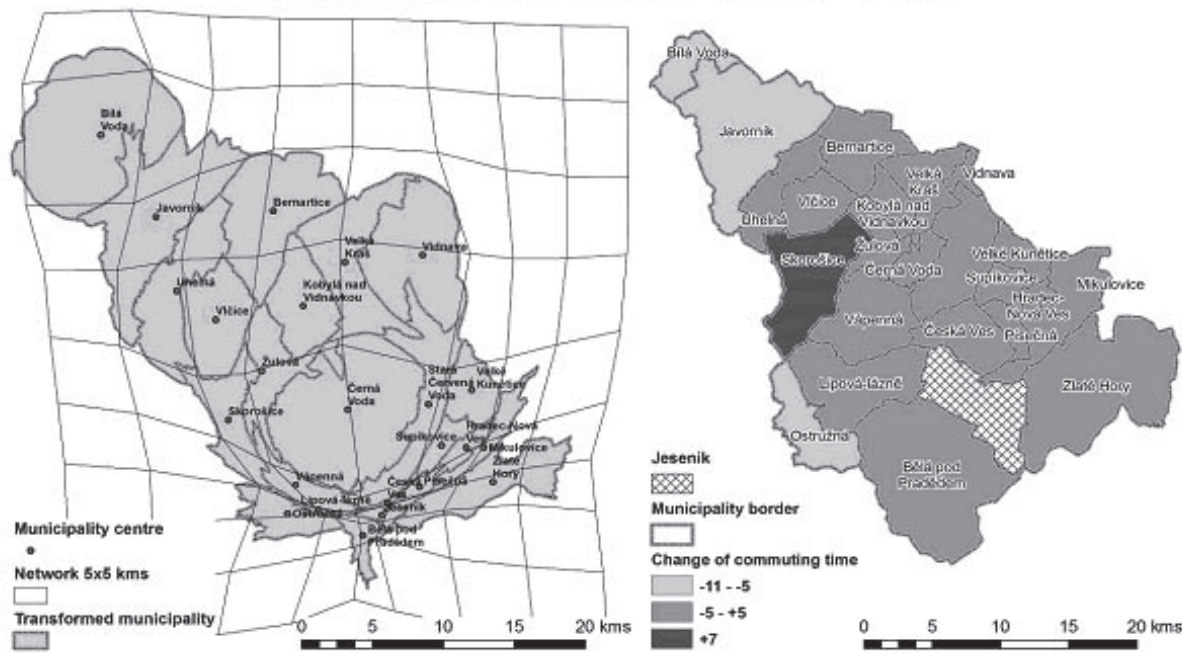

Figure 3. Commuting time of PT connections to Jeseník Source: own creation. 


\section{WALKING DISTANCES TO STOPS}

Walking distances can have very significant influence on the total commuting time and can even double the total journey time (Ivan 2009). Various data sources were used for the evaluation of walking distances to the closest stop for the way of commuting to work in the Jeseník region. As the data source about buildings with localization and other buildings attributes was used the Register of census areas and buildings (Czech Statistical Office) valid to 1/7/2008. Median of walking distances to two nearest stops (without transport type resolution) were calculated and then recalculated to time distance with average walking speed $4.8 \mathrm{kph}$. The same procedure was done for walking distances and times separately to bus and train stops.

Table 1. Median of distance to two closest PT stops (selection of municipalities)

\begin{tabular}{||l|c|c|c|c||}
\hline \multirow{2}{*}{ Municipality } & \multicolumn{2}{|c|}{ Time of walk [min] } & \multicolumn{2}{c||}{ Distance of walk [m] } \\
\cline { 2 - 5 } & Closest stop & Farther stop & Closest stop & Farther stop \\
\hline Bílá Voda & 6.3 & 17.8 & 502.1 & 1425.5 \\
\hline Javorník & 5.2 & 8.5 & 416.3 & 681.1 \\
\hline Jeseník & 5.3 & 9.6 & 423.4 & 767.7 \\
\hline Lipová-lázně & 3.5 & 5.8 & 283.0 & 462.3 \\
\hline Mikulovice & 5.9 & 11.1 & 472.7 & 890.8 \\
\hline Ostružná & 9.6 & 11.8 & 764.1 & 945.2 \\
\hline Písečná & 5.9 & 12.4 & 472.9 & 995.0 \\
\hline Skorošice & 7.1 & 13.2 & 564.2 & 1052.6 \\
\hline Vidnava & 5.2 & 10.3 & 418.3 & 823.6 \\
\hline Zlaté Hory & 4.2 & 6.7 & 333.2 & 533.9 \\
\hline Žulová & 3.7 & 6.4 & 298.7 & 514.5 \\
\hline Jeseník region & $\mathbf{5 . 0}$ & $\mathbf{9 . 7}$ & $\mathbf{4 0 3 . 2}$ & $\mathbf{7 7 4 . 5}$ \\
\hline Source: own ca. & & & \\
\hline
\end{tabular}

Source: own calculations.

The tabular output is the result of walking distance analysis to stops, where there is median of distances of walk to two nearest stops for each municipality from all buildings in minutes and metres. Median was chosen because it is less than the average in case of all municipalities due to influence of high (mostly extreme) values of walking distances from remote buildings. In the table there are not shown all municipalities but only a selection of 11 municipalities. These municipalities belong to most significant and the situation there is interesting from the walking distance and time point of view. The median of time of walk to the closest stop in Jeseník region is 5 minutes (400 metres), if there is important to use farther stop, commuter has to walk twice longer journey so it takes almost 10 minutes (775 me- 
tres). There are evident some exceptions in the region. Inhabitants in Ostružná have to walk the longest distance to the closest stop, almost 10 minutes ( 764 metres), but the second closest stop is only about 180 metres farther, what is the smallest difference of all municipalities, but still above the regional average. People in Bílá Voda must rely on the closest stop which is 6 minutes of walk away, because the second stop is very remote, almost 1,5 kilometre away, what is the biggest difference of walking distance between first two closest stops. The best situation is in municipalities like Lipová-lázně, Zlaté Hory and Žulová. The closest stop is distanced only 4 minutes of walk and the distance to second stop is below the regional average as well (about 6 minutes of walk).

Situation in the region is spatially described in the map below. In the first map field there is another anamorphic map where the area is expanded or collapsed based on the median of walking distance to the closest stop in particular municipality. The second map field describes the same problematic but with different cartographic method. In this map, the symbol size is proportional to the median of distance to the closest stop. The most significant area expand is evident in the east central part of the region (Supíkovice, Velké Kunětice, Písečná, Hrade-Nová Ves, Mikulovice). The other larger areas are created by municipalities Bernartice and Vlčice. On the other hand, there are evident some municipalities where the area collapsed because of small distance to stop. This is the situation of Zlaté Hory, Lipová-lázně, Javorník, Žulová.

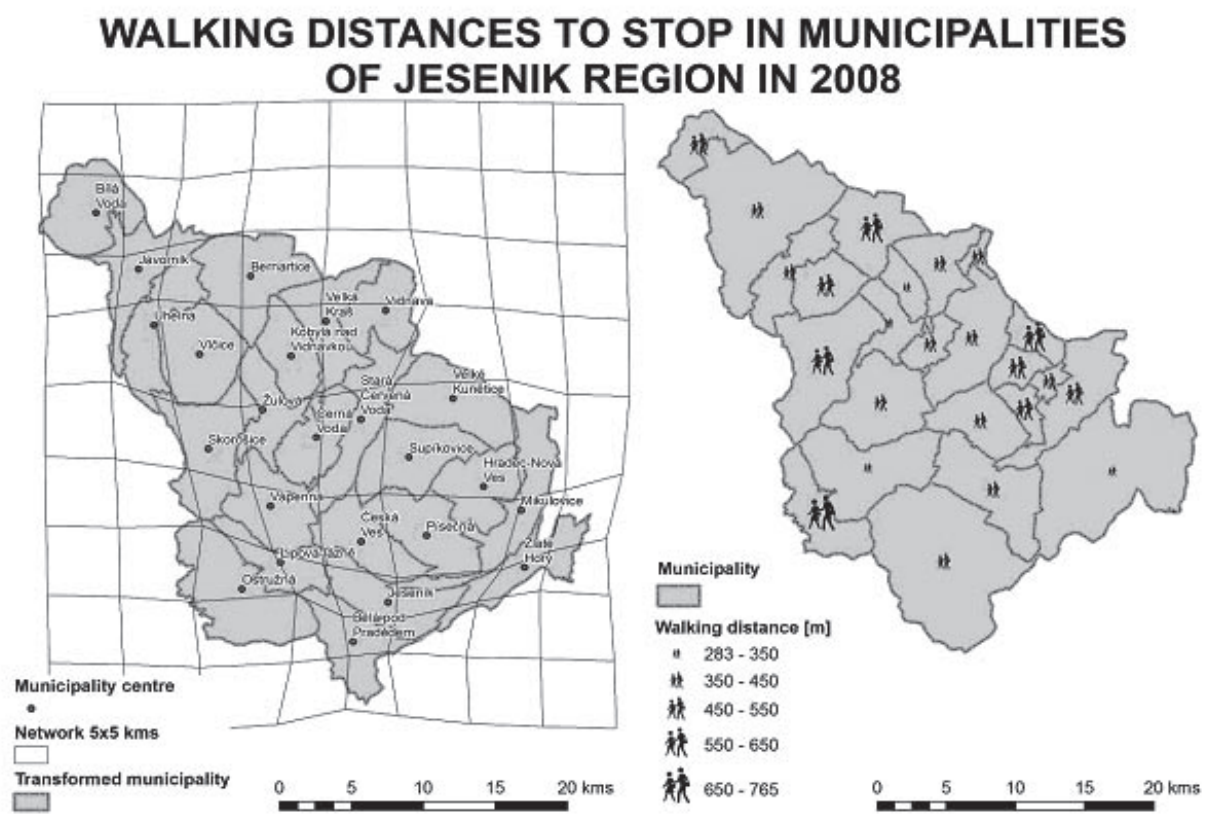

Figure 4. Median of walking distances to the closest stop Source: own creation. 
Next table contains medians of distances to closest train and bus stop in selected municipalities where both types of transport system are provided. The average distances for the whole region prove the hypothesis that train stops are more remote than bus stops. The difference is averagely 7.5 minutes or almost 600 metres. This is mostly influenced with bigger number of bus stops in particular municipalities, the link network is much denser in case of bus system than in case of train network. Other purpose is the historical main reason of railways - to provide transport for goods, mostly wood from local forests. That is why these train stations are located mostly outside the municipality centre.

Table 2. Median of distance to bus and train stop (selection of municipalities)

\begin{tabular}{|l|r|r|r|r|}
\hline \multirow{2}{*}{\multicolumn{1}{|c|}{ Municipality }} & \multicolumn{2}{|c|}{ Distance of walk [m] } & \multicolumn{2}{c|}{ Time of walk [min] } \\
\cline { 2 - 5 } & Bus & Train & bus & train \\
\hline Bělá pod Pradědem & 747.3 & 1205.8 & 9.3 & 15.1 \\
\hline Bernartice & 369.7 & 866.0 & 4.6 & 10.8 \\
\hline Česká Ves & 432.0 & 988.9 & 5.4 & 12.4 \\
\hline Hradec-Nová Ves & 421.8 & 1326.1 & 5.3 & 16.6 \\
\hline Javorník & 423.4 & 1746.3 & 5.3 & 21.8 \\
\hline Jeseník & 338.6 & 786.8 & 4.2 & 9.8 \\
\hline Kobylá nad Vidnavkou & 313.5 & 828.5 & 3.9 & 10.4 \\
\hline Lipová-lázně & 478.2 & 1255.4 & 6.0 & 15.7 \\
\hline Mikulovice & 773.0 & 954.4 & 9.7 & 11.9 \\
\hline Ostružná & 472.9 & 1362,2 & 5.9 & 17,0 \\
\hline Písečná & 442.3 & 980.4 & 5.5 & 12.3 \\
\hline Vápenná & 461.6 & 735.6 & 5.8 & 9.2 \\
\hline Velká Kraš & 418.3 & 834.5 & 5.2 & 10.4 \\
\hline Vidnava & 339.3 & 1228.6 & 4.2 & 15.4 \\
\hline Zlaté Hory & 331.7 & 744.1 & 4.1 & 9.3 \\
\hline $\begin{array}{l}\text { Average of selected } \\
\text { municipalities }\end{array}$ & 450.9 & 1056.2 & 5.6 & 13.2 \\
\hline
\end{tabular}

Source: own calculations.

The average walking time to the closest train station in this region is slightly above 1 kilometre, what means 13 minutes of walk. The worst situation with train stop accessibility is in Javorník. The stop is located very far from the centre (see the picture below) and potential train users have to walk more than 1700 metres (almost 22 minutes of walk). On the other hand, the shortest distance to train stop is in case of Vápenná and Zlaté Hory (less than 800 metres and 10 minutes), but in these cases, rail stations are located outside the centre as well. Interesting situation is in Lipová-lázn, where are very good PT connections to Jeseník via trains, but location 
of train stops ( 3 stops) is problematic and that is why people here must walk long distance away (more than 15 minutes). Bus stops are averagely distanced about 450 metres (almost 6 minutes). But there are only two municipalities from the table above, where the distances are significantly bigger (Mikulovice and Bělá pod Pradědem) what is caused by the type settlement (see above).

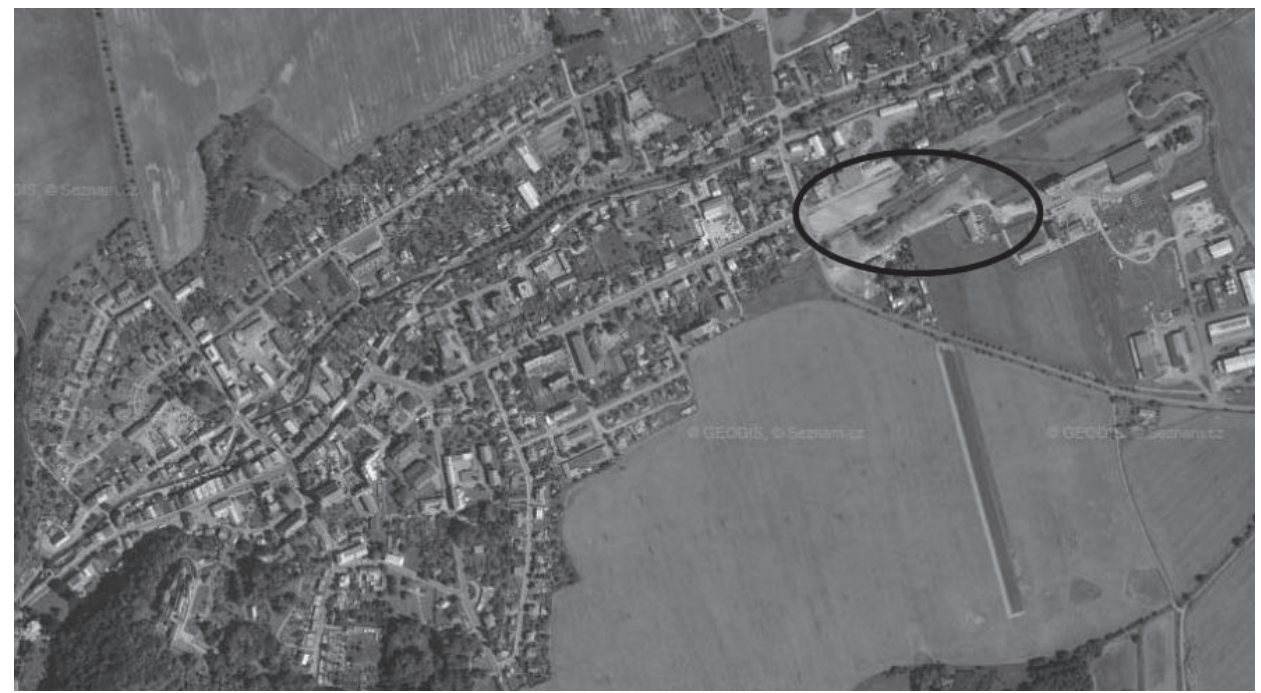

Figure 5. Javorník municipality-distance between train station and municipality centre Source: (C) GEODIS, (c) seznam.cz.

The map below describes the situation to the closest stop in two significant cities in the region-Jeseník and Javorník. There are four map fields on the map. Situation in Javorník is visualised in first row and in the second row there is situation in Jeseník. First column in for bus transport system and second column for train transport system. In Javorník, the density of bus stops is sufficient and there is evident only small area with distance above 500 metres. That is why the median of distance to the closest stop is below the regional average. In case of train transport system, the situation is completely different. The municipality suffers from remote train station and most of all buildings are quite remote (more than 1 kilometre). This ranks Javorník station to most remote train stop in Jeseník region.

The situation in Jeseník is more complicated because of denser stops network and densely populated area. Train station accessibility in Jeseník belongs to best in region, but still many buildings are quite remote from the station. In case of bus stops, there is evident interesting situation. Five bus stops are located around train station, so this area is very well serviced, but situation in south-east part of the city is completely different. There is no stop at all, so people from this area have to walk quite a long journey to the closest stop (more than 750 metres). 


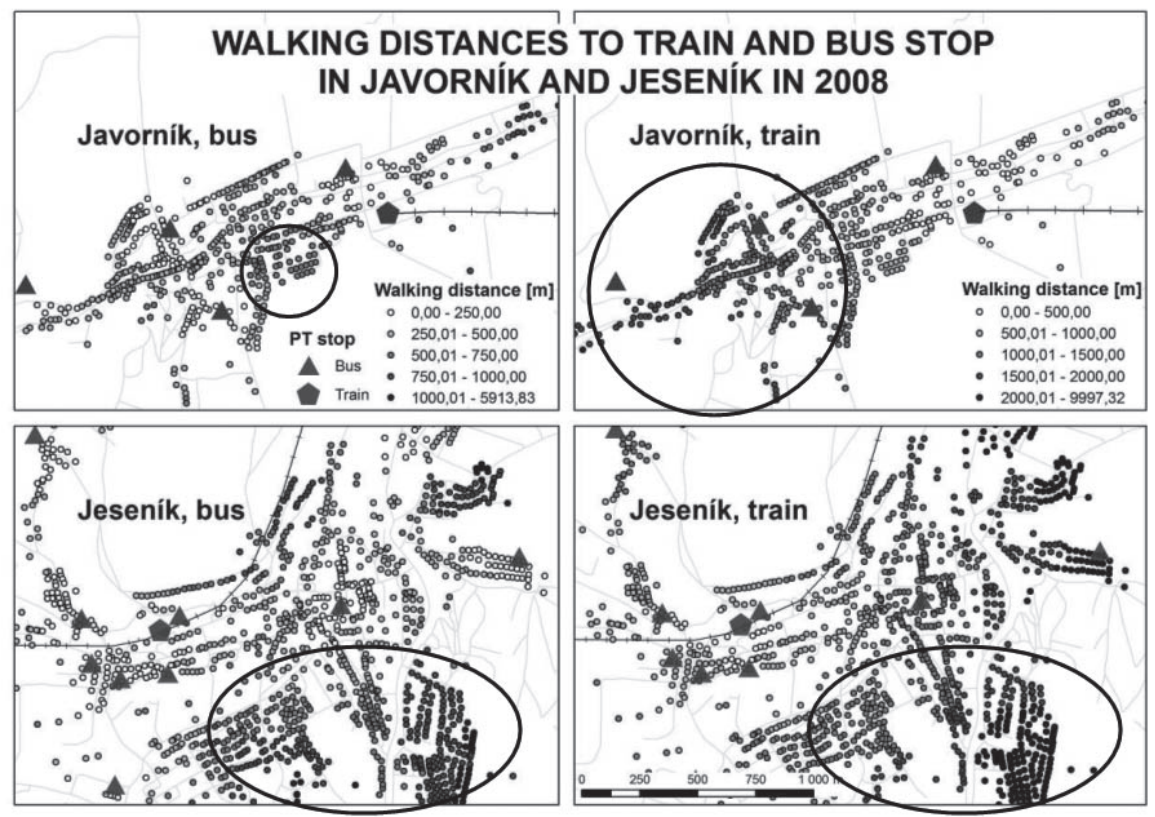

Figure 6. Javorník and Jeseník municipality—distance to closest train and bus stop Source: own creation.

\section{INHABITANTS' OPINION ON PT}

Subjective opinions of affected public have important impact of PT demand: their perception of quality and quantity of PT services. On-demand management of PT is today's important approach of transportation planning. Questionnaire survey is one of the qualitative tools to determine public opinion. Mismatch between the "objective" level of supply and the customer (or potential customer) opinions is heavily underestimated by suppliers (municipalities and the Regional Authority) as well as by providers of transport services. Mobility marketing is not yet developed in transport policy at all hierarchical levels in case of the Czech Republic.

In April 2008, the questionnaire survey was made by the research team in the Jeseník region. It was used so called quota method (in every municipality, there was an adequate number of questionnaires to the percentage of the population in the village, based on the total population of the region and the segmentation of respondents according to basic demographic characteristics). Statistically, 407 questionnaires were collected (mostly they are residents and short-term migrant citizens which commute to work or schools). The survey was primarily focused on the overall perception of socio-economic situation of the inhabitants in the region and also it included issues related to the transport behaviour of them. $43 \%$ respondents of survey are the daily commuters. 
The results show that $65 \%$ of all respondents are satisfied with public transport service in the region (in which more than a half are "quite satisfied"), which is a very high share, according to "rural standard" of Jeseník region. Furthermore, it was found that there exists a statistically significant difference between the evaluation of two groups of economically non-active inhabitants-young people, under the age of 15 and seniors over the age of 65 and more years. While the young people are not satisfied with the traffic in $20 \%$ of cases, almost $34 \%$ of elderly people are satisfied. Most dissatisfied with transport there are paradoxically, non-users or occasional users of HD, which actually own a car. This paradox is also well known from other surveys of transport behaviour-negative public opinion on the quality of the PT, particularly among the users of individual mobility (and thus potential customers of the PT) is changed very little or not at all.

Map (Figure 6) shows the level of satisfaction with transport availability in these municipalities. The position of the Lipová-lázně is interesting about this and as well the region centre, city Jeseník, where satisfaction is lower while the "objectivity" supply is the best when we compare it with other municipalities. The reasons behind the greater degree of criticism may be different; however, we feel that the inhabitants' meanings in city Jeseník are affected by the regional connections supply (i.e. connections to and from the region, such as to Šmperk and Olomouc). Another reason for discontent, there is the objective existence of the long walking distances to stops (also an example of Lipová-lázně municipality in the case of train transportation, see chapter 5).

Satisfaction with public transport services year 2008

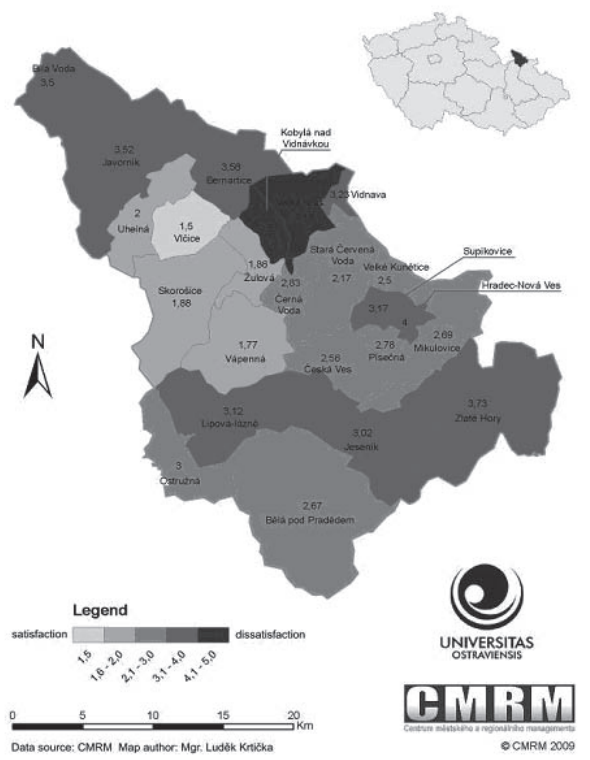

Figure 7. Inhabitants's satisfaction of public transport services Source: CMRM 2009@. 


\section{CONCLUSION}

PT supply is stabilized and in absolute terms of connections it is better in comparison with year 2003. The size of demand is equal to actual trends despite of small decrease (less than country average) and it can be considered as a success (see Table no. 3). Qualitative research, which was realised in the region, proved as well the relative satisfaction of inhabitants with PT service. Unfortunately, this positive situation of the PT level is not used for marketing issues or campaigns. Commuting times from 23 municipalities to the core (city Jeseník) are as well better in 2008 than in 2003, in case of commuting for morning shift. In the Javorník’s hook (Bílá Voda and Javorník) is evident progress, but commuting times in this area belongs still to most time-consuming. Environmentally friendlier railway does not supply more attractive travel times in the door-to-door meaning approach to bus transport. There is only one exception that the travel time via train is faster than via bus transport (municipality Zlaté Hory). In addition, walking distances to stops are much longer in case of railway.

Table 3. Number of transported passengers by bus provider within the Jeseník region

\begin{tabular}{|c|c|c|c|c|c|c|}
\hline Year & 2003 & 2004 & 2005 & 2006 & 2007 & 2008 \\
\hline $\begin{array}{c}\text { Transported } \\
\text { passengers }\end{array}$ & 2889682 & 2878686 & 2848586 & 2813471 & 2769115 & 2754870 \\
\hline
\end{tabular}

Source: Veolia Transport Morava, Inc. (2008).

Walking distance to PT stops is quite big in the whole region and it enlarges total time of commuting. Because of the area character, another important influence on the walking process has the weather, as well as the relief and its character (pathway, road) and equipment of particular stop (roof, leeward, bike rack, cleanness etc.). We showed that the character and form of settlement can have significant influence on the walking distances not only in case of train transport system but also in case of bus transport system.

\section{REFERENCES}

Boruta, T. and Ivan, I. (2008), Dopravní obslužnost hromadnou dopravou na Jesenicku, Ph.D. Workshop Proceedings, ÚGN, Ostrava, 9-14.

Dijst, M. (1999), Two-earner families and their action spaces: A case study of two Dutch communities, GeoJournal, 48, (3), 195-206.

Fojtík, D., Horák, J., Šeděnkévá, M., Ivan, I. (2009), Software support for automatic creating database of public transport connections, in: Proceedings of 10th International Carpathian Control conference, Zakopane, Poland, 517-520.

Green, M.B., Meyert, S.P. (1997), An overview of commuting in Canada with special emphasis on rural commuting and employment, Journal of Rural Studies, 13, (2), 163-175. 
Hampl, M. (2005), Geografická organizace společnosti v České republice: Trasformační procesy a jejich obecný kontext, Univerzita Karlova, Praha.

Horák, J., Šeděnková, M., Ivan, I. (2008), Modelling of public transport accessibility for municipalities in the Czech Republic. Available from: < http://gisak.vsb.cz/ iva026/ source/ReferatHorakDopravaFinal.pdf>

Hůrský, J. (1969), Zjištovací intenzity dopravního zpř́stupňování (Morava a Slezsko 1891-1955). Feststellung der Intensität der Verkohrserreichbarkeit (Mähren und Schlesien 1891-1955). HG 2, 1969, 79-87, 3 mp.

Hůrský, J. (1978), Metody oblastního členění podle dopravního spádu, Rozpravy ČS AV, Issue 88-3.

Ivan, I. (2009), Commuting, why door-to-door approach? The situation in MoravianSilesian Region of the Czech Republic, in: Krek, A., Rumor, M., Zlatanova, S. \& Fendel, E.M. (eds.) Urban and regional data management. Taylor \& Francis Group, London, 439-453.

Ivan, I., Horák, J., Šeděnková, M. (2009), Public transport accessibility in the Czech Republic, in: Proceedings Territorial Cohesion of Europe and Integrative Planning, ERSA 2009 — the 49th European Congress of the Regional Science Association International, Łódź.

Kvizda, M., Pospíšil, T., Seidenglanz, D., Tomeš, Z. (2007), Železniční dopravainstitucionální postavení, hospodářská politika a ekonomická teorie, Masarykova univerzita, Brno.

Láznička, Z. (1956), Typy venkovského osídlení v Československu, in: Práce brněnské základny československé akademie věd-sešit 3, 1. edition, ČSAV, Brno.

Lijewski, T. (1967), Dojazdy do pracy w Polsce, PWN, Warszawa.

Marada, M. (2003), Dopravní hierarchie středisek v Česku: vztah k organizaci osídlení, Ph.D. Thesis, Praha: UK.

Nutley, S. (1998), Rural areas: accessebility problem, in: Hoyle, B.and Knowles, R. (eds.) Modern Transport Geography, 2. edition, Wiley and Sons, Chichester.

Pucher, J. (2002), Suburbanizace př́městských oblastí a doprava: mezinárodní srovnání, in: Sýkora, L. (ed.) Suburbanizace a její sociální, ekonomické a ekologické důsledky, Ústav pro ekopolitiku, Praha, 101-121.

Rumpel, P. and Wilam, P. (2006), Studie proveditelnosti preshraničního regionu partnerství EURES-T Beskydy.

Rumpel, P., Boruta, T., Novák, D.W. (2009), Analýza př́čin regionálních disparit v modelovém regionu Jesenicko v kontextu teorie regionálního marketingu, Ostravská univerzita, Ostrava.

Sandow, E. (2008), Commuting behaviour in sparsely populated areas: evidence from northern Sweden, Journal of Transport Geography, 16, (1), 14-27.

Seidenglanz, D. (2007), Dopravní charakteristiky venkovského prostoru. Ph.D. Thesis, Brno. Taylor, Z. (2003), Accessibility to facilities versus daily mobility of rural dwellers: the case of Poland, in: Higgs G. (ed.), Rural services and social exclusion, European Research in Regional Science, 12, 95-125, Pion, London.

White, P. (2001), Public transport, Spon Press, London.

Woods, M. (2005), Rural geography, Sage, London. 
http://rcin.org.pl 